\title{
A Birthday Wish
}

\author{
Meredith Lash, MD
}

Weill Cornell Medical College, New York, NY, USA.

$\mathrm{T}$ oday my great-aunt Becky turns 105 years old. When I tell people she is celebrating this milestone, after the initial expression of amused surprise, questions begin. Does she live alone? Does someone help take care of her? Is she still "with it"? Then come deeper probes: does she have her own teeth? Does she need a diaper?

After the questions come the inevitable reflections on age and mortality. Some people will comment that they never want to reach that kind of advanced age, but often I'm told how lucky I am to come from a family line with that kind of longevity.

Becky herself no longer feels lucky. She did for a while, attributing her intact health to avoiding doctors in general and their medications in particular. She still cracks this joke to me, but the twinkle in her eye has long been replaced with the refraction of a new lens after cataract surgery. She is still alert and her memory is relatively preserved, but memory is almost all that is left. She repeats the same stories, not because she's forgotten whether you've heard them but because she has had no recent new experiences on which to comment. Her sisters and her friends are deceased-even her friend's children are starting to pass. She has watched family members half her age fall ill and succumb even as she herself wishes for release.

A common theme is her lament against Medicare. "They take my money and I get nothing back for it." Each time, I remind her that the only way to get return on her dollar is to fall sick. Logic fails, however, as she becomes progressively upset about the lack of return on her mandated investment. My patience falters. I nearly yell, "Get sick. Go to the hospital. Recoup your losses!" I hold my tongue and simply remind her how lucky she is to have so little need of Medicare. She looks at me with an expression that clearly states that I have much to learn and she lacks the time and energy to teach me.

She tells me almost daily that she's ready to go. She offers herself up nightly in place of younger family members whose health is in jeopardy, but still she wakes to greet the new day.

Published online April 3, 2012
She can't watch TV; her eyesight is too limited. She can't hear music on the radio. She can't hear to use the phone, and even if she could, she cannot see the numbers well enough to dial. And, as mentioned, she has a progressively narrowing cadre of telephone correspondents. She is in virtual solitary confinement.

Becky was a vivacious, well-traveled, literate, attractive woman. She was proud nearly to the point of being slightly full of herself. She was born the middle of five sisters and needed to distinguish herself; she did so by living a more glamorous life than her sisters who generated a prodigious number of offspring. She nurtured all of her many nieces and nephews but, by choice or by fate, had no child of her own.

That woman is now half of her former height, half of her former weight. She sleeps poorly though the night and wakes late in the mornings. She lingers over breakfast, prolonging the time until she is left with little to do except wait for lunch. She concludes lunch and waits for dinner; eating is one of her few remaining pleasures. She hopes for visitors who sometimes come but more often do not. When she is fortunate enough to have company she tries to contribute to the conversation but the effort exhausts her. Her most fruitful conversations are the ones she holds with loved ones who have departed years before.

I wonder if years ago, she blew out her candles and wished to live to a ripe old age. Happy Birthday, Aunt Becky. May your birthday wish come true.

Corresponding Author: Meredith Lash, MD; Weill Cornell Medical College, 211 East 80th Street, New York, NY 10076, USA (e-mail: Mfl9002@med.cornell.edu).

J Gen Intern Med 27(10):1389

DOI: $10.1007 / \mathrm{s} 11606-012-2039-\mathrm{Z}$

(C) Society of General Internal Medicine 2012 